\title{
Effect of a spray formulation on the reproductive parameters of a susceptible population of Rhipicephalus (Boophilus) microplus
}

Efeitos de uma formulação pulverização sobre os parâmetros reprodutivos de uma população susceptível de Rhipicephalus (Boophilus) microplus

\author{
Breno Cayeiro Cruz ${ }^{1}$; Welber Daniel Zanetti Lopes ${ }^{1,2 *}$; Willian Giquelin Maciel ${ }^{1}$; Gustavo Felipelli ${ }^{1}$; \\ Weslen Fabricio Pires Teixeira ${ }^{1}$; Flavia Carolina Favero ${ }^{1}$; Luciana Prando ${ }^{1}$; Carolina Buzzulini ${ }^{1}$; Vando Edesio Sorares ${ }^{1}$; \\ Lucas Vinicius Costa Gomes ${ }^{1}$; Murilo Abud Bichuette ${ }^{1}$; Alvimar José da Costa ${ }^{1}$ \\ ${ }^{1}$ Centro de Pesquisas em Sanidade Animal - CPPAR, Faculdade de Ciências Agrárias e Veterinárias, Universidade Estadual Paulista - \\ UNESP, Jaboticabal, SP, Brasil \\ ${ }^{2}$ Universidade Federal de Goiás - UFG, Regional de Jataí, GO, Brasil
}

Received February 17, 2014

Accepted July 25, 2014

\begin{abstract}
The number of studies emphasizing the possible damage that acaricidal spray formulations can cause on engorged female ticks' reproductive parameters is small. The present study evaluated the deleterious effects of a spray formulation (dichlorvos 60\% + chlorpyrifos 20\%) on the reproductive parameters of a susceptible population of Rhipicephalus (B.) microplus females, using the Stall Test. The ticks were allocated randomly to treatments according to the mean numbers of females detached from each cow on days $-3,-2$ and -1 and the cattle pen location. The numbers of engorged female ticks that naturally detached from the cattle were counted daily from day 1 to day 30. For each group, 20 detached engorged female ticks or the available number collected daily were evaluated regarding reproductive parameters. Associations of organophosphates demonstrated elevated acaricidal efficacy, as well as deleterious effects on the reproductive parameters of $R$. (B.) microplus females. The engorged female weight (days 1 to 7 ), weight of egg masses (days 5 to 10$)$ and larval hatching percentage (days 5 to 19$)$ were decreased $(\mathrm{P} \leq 0.05)$. It is possible that a formulation can lead to deleterious effects on $R$. (B.) microplus females when the tick population analyzed shows elevated sensitivity towards a particular formulation. However, further studies need to be conducted.
\end{abstract}

Keywords: Cattle tick, dichlorvos 60\% + chlorpyrifos 20\%, susceptible population, reproductive efficiency, $R$. (B.) microplus.

\section{Resumo}

É relativamente pequeno o número de estudos que enfatiza os danos que uma formulação acaricida spray pode desencadear sobre os parâmetros reprodutivos das teleóginas. O presente estudo teve como objetivo avaliar os efeitos deletérios de uma formulação spray comercial (dichlorvos 60\% + Clorpirifós 20\%), sobre os parâmetros reprodutivos de uma população susceptível de $R$. (B.) microplus, desprendidas de bovinos experimentalmente infestados, utilizandose o teste de estábulo. Os animais foram alocados aos grupos de tratamentos de acordo com a contagem média de fêmeas desprendidas dos bovinos nos dias $-3,-2$ e -1 . O número de teleóginas desprendidas foi quantificado do dia 1 ao 30 . Para cada grupo, diariamente 20 fêmeas, ou a quantidade disponível, foram selecionadas e submetidas à avaliaçấo dos parâmetros reprodutivos. A associação de organofosforados demonstrou elevada eficácia acaricida e também apresentou efeitos deletérios sob os parâmetros reprodutivos de Rhipicephalus (B.) microplus, diminuindo $(\mathrm{P} \leq 0,05)$ o peso das teleóginas (dos dias 1 ao 7), o peso da massa de ovos (dos dias 5 ao 10) e a eclodibilidade das larvas (dos dias 5 ao 19). Talvez uma formulação pode apresentar efeitos deletérios sobre os parâmetros reprodutivos de fêmeas de $R$. (B.) microplus, quando existe um elevado grau de sensibilidade dessa cepa de carrapato a um determinado composto. De qualquer maneira, futuros estudos devem ser realizados.

Palavras-chave: Carrapato bovino, dichlorvos $60 \%$ + chlorpyrifos $20 \%$, população susceptível, eficiência reprodutiva, $R$. (B.) microplus. 


\section{Introduction}

Rhipicephalus (Boophilus) microplus is considered to be the most important ectoparasite in cattle industry because of the direct and indirect damage it can cause to animal health, thereby considerably limiting bovine productivity (CALLIGARIS et al., 2013; FAZA et al., 2013). It possesses a wide geographical distribution, encompassing tropical and subtropical regions situated between the parallels $32^{\circ}$ latitude north and $35^{\circ}$ latitude south, comprising countries in Latin America, Africa, Asia and Oceania (WHARTON, 1974).

Control over these parasites is essentially based on using chemical products (FURLONG, 2005; KLAFKE et al., 2006). Pereira et al. (2008) reported that in order to control $R$. (B.) microplus, it is necessary to remember that only $5 \%$ of the parasites are located in the host, meaning that the remaining 95\% stay in the environment. Based on this idea, several studies (GONZALES et al., 1993; GEORGE \& DAVEY, 2004; PEREIRA, 2009; LOPES et al., 2013) have emphasized that successful control over a tick population on a given farm is related not only to great efficacy of a certain acaricide, but also to the deleterious effects that these active agents have on tick populations in the field, especially in relation to the reproductive parameters of engorged $R$. (B.) microplus females. This effect, caused by some formulations, is called "pasture cleansing" (PEREIRA, 2009; SANTANA et al., 2013).

On the other hand, the number of studies emphasizing the possible damage that acaricidal spray formulations can cause to engorged females' reproductive parameters is relatively small. On this basis, the present study aimed to evaluate the deleterious effects of a spray formulation available on the market (Ectofós ${ }^{\odot}$ spray, Vallée, which contains 60\% dichlorvos (DDVP) $+20 \%$ chlorpyrifos $20 \%$ ), in relation to the reproductive parameters of engorged $R$. (B.) microplus females, detached from experimentally infested cattle.

\section{Materials and Methods}

\section{Location, animals and pretreatment infestations}

This experiment was conducted at the Animal Health Research Center (Centro de Pesquisas em Sanidade Animal, CPPAR), at the School of Agrarian and Veterinary Sciences (FCAV), UNESP, Jaboticabal, state of São Paulo, Brazil.

Sixteen crossbred cattle, aged approximately seven months, which had not received any antiparasitic treatment for the last 90 days, were selected and identified (numbered ear tags). In this study, all the procedures using animals complied with the Ethical Principles for Animal Research adopted by the College of Animal Experimentation (COBEA) and were approved by the Ethics Committee for Animal Welfare, Institute of Animal Health Research (IPESA), Formiga, Minas Gerais, Brazil, under procedural number PP 003G1/2012. All the animals were kept in individual suspended stalls and were infested with approximately $5000 R$. (B.) microplus larvae (0.25 grams of eggs) of mean age 14 days, on days $-24,-21,-19,-17,-14,-12,-10,-7,-5,-3$ and -1 , taking day 0 as the treatment date (Brasil, 1997). This strain of $R$. (B.) microplus was obtained from fields at a farm in Formiga, Minas Gerais) and is now kept at CPPAR, using cattle and a BOD incubator. All procedures using infestations of animals in order to maintain colonies also complied with the Ethical Principles for Animal Research adopted by the College of Animal Experimentation (COBEA) and were approved by the Ethics Committee for Animal Welfare, IPESA, Formiga, Minas Gerais, Brazil, under procedural number PP 001B1/2011.

\section{Counting engorged $R$. (B.) microplus females detached from cattle before treatment and allocating animals to treatment groups}

On days $-3,-2$ and -1 , fully engorged $R$. (B.) microplus females that detached from each animal were counted. All counts were performed daily in the mornings (between 08:00 and 09:00 am). Animals were allocated randomly to treatments in accordance with a randomized complete block design. The block formation was based on the arithmetic mean number of female ticks detached from each animal prior to treatment (days -3, -2 and -1) and the cattle pen location. The cattle were divided into eight blocks of two animals each and, within each block, animals were randomly placed in one of the treatment groups: in T01, the animals were kept as controls; and in T02, the cattle received 60\% dichlorvos $+20 \%$ chlorpyrifos via spray. The blocks were assigned to sets of two nearby cattle pens, and the animals within each block were randomly allocated to cattle pens within the set. The experimental unit was the animal. The formulation was administered in accordance with the manufacturer's recommendations.

\section{Counting engorged $R$. (B.) microplus females detached from each animal and post-treatment infestations}

Engorged female ticks that naturally detached from the cattle were counted daily from day 1 until the end of the experiment (day 30). During the post-treatment period, all the cattle were infested with approximately 5000 viable unfed larvae twice a week (every Tuesday and Thursday of each week), up to the end of the study, as recommended by Holdsworth et al. (2006).

\section{Assessment of the reproductive parameters of the preselected engorged female ticks}

The following reproductive parameters of the engorged female ticks were analyzed: female weight, egg mass weight, percentage hatchability, percentage reduction in oviposition, percentage reduction in hatchability, reproductive efficiency and percentage control/efficacy of formulations with regard to reproductive parameters.

For this analysis, all the engorged female ticks that detached from the animals were collected every morning from day 1 until the end of the experiment (day 30), as described above. For each group, 20 detached engorged female ticks or the available number collected daily were randomly selected, weighed, fixed 
on Petri plates and moved to a BOD incubator at $27{ }^{\circ} \mathrm{C}$ and approximately $85 \%$ relative humidity to stimulate oviposition. Twenty days after oviposition in the BOD incubator, the egg mass weight of the engorged female ticks was recorded for each group and post-treatment day. Subsequently, the egg mass of each group and post-treatment day was transferred to adapted 3 - $\mathrm{mL}$ syringes and was returned to the BOD incubator at $27^{\circ} \mathrm{C}$ and approximately $85 \%$ relative humidity to stimulate larval hatching. After 20 days of larval hatching in the BOD incubator, the percentage hatchability was calculated in accordance with the methodology described by Gonzales et al. (1993). The percentage hatchability of each sample group (derived from the daily sample of detached preselected engorged female ticks) was visually estimated using a stereomicroscope with an ocular grid, by comparing the proportion of larvae in relation to the proportion of unhatched eggs for each group and post-treatment day (DRUMMOND et al., 1973; GONZALES et al., 1993; GEORGE \& DAVEY, 2004; HOLDSWORTH et al., 2006).

\section{Percentage efficacy}

\section{Reduction in the number of engorged females counted}

The acaricidal efficacy of the formulation was calculated using arithmetic means from the counts of engorged female ticks that detached from the animals of each group. The data collected were grouped into three-day intervals.

$$
\text { Percent efficacy }=\left[1-\frac{\mathrm{Ta} \times \mathrm{Cb}}{\mathrm{Tb} \times \mathrm{Ca}}\right] \times 100
$$

where $\mathrm{Ta}=$ average number of engorged female ticks counted on treated animals post-medication;

$\mathrm{Tb}=$ average number of engorged female ticks counted on treated animals during the 3 days prior to treatment;

$\mathrm{Ca}=$ average number of engorged female ticks counted on control animals after the experiment began;

$\mathrm{Cb}=$ average number of engorged female ticks counted on control animals during the 3 days prior to treatment.

\section{Reproductive parameters of pre-selected engorged female ticks}

To assess the impact of treatment on the reduction of oviposition and hatching, the following equations were used:

$$
\begin{aligned}
\% \text { reduction in oviposition }= & \begin{array}{l}
\text { average egg mass weight of control group }- \\
\text { average egg mass weight of treated group }
\end{array} \\
\text { average egg mass weight of control group } & \text { average hatchability of control group }- \\
\% \text { reduction in hatching }= & \frac{\text { average hatchability of treated group }}{\text { average hatchability of control group }} \times 100
\end{aligned}
$$

To estimate the extent of reproduction and percentage of control/efficacy, the following equations were used:

$$
\begin{aligned}
& \text { Estimate of reproduction }(\text { ER })=\frac{\text { egg weight }(\mathrm{g})}{\text { female weight }(\mathrm{g})} \times \% \text { hatching } \times 20,000^{1} \\
& \% \text { control or efficacy }=\frac{\text { ER of control group }- \text { ER of treated group }}{\text { ER of control group }} \times 100
\end{aligned}
$$

\section{Data analysis}

The data pertaining to the reproductive parameters of the naturally detached and pre-selected engorged female ticks from the experimental groups (engorged female weight, egg mass weight and percentage hatchability) were analyzed using a completely randomized design. The differences between mean values were compared using Tukey's test at a confidence level of $95 \%$.

For the raw counts on all the detached engorged female ticks, the data were grouped into three-day intervals and log transformed $[\ln ($ tick count +1$)]$. A generalized linear mixed model for repetitive sampling was applied using SAS (SAS Institute, 1996) to assess the fixed effects of the treatment, the tick counts, the interaction between treatment and counts, the random block effects and the random residual effects.

\section{Results and Discussion}

From analysis on the results from the statistical analysis, grouped at three-day intervals, on the reproductive parameters of the $R$. (B.) microplus females that were exposed to wholebody spraying of the dichlorvos + chlorpyrifos combination, it could be seen that the fully engorged females that detached and were preselected from animals that received the aforementioned formulation were statistically lighter $(\mathrm{P} \leq 0.05)$ than the female ticks of the control group, from the $1^{\text {st }}$ to the $7^{\text {th }}$ day posttreatment (DPT) (Table 1).

The females in the group treated with the organophosphate association (dichlorvos + chlorpyrifos) presented a deleterious effect regarding egg mass weight, such that the egg mass was lighter than that of the control group between the $5^{\text {th }}$ and $10^{\text {th }}$ DPT (Table 1). The action of dichlorvos + chlorpyrifos producing lower-weight female ticks and egg masses may have diminished the hatchability values of the treated group, which were lower than the values obtained for the control group from the $5^{\text {th }}$ to the $19^{\text {th }}$ DPT (Table 1).

Table 2 shows the grouped results from the 30 post-treatment days. Based on data from this table, it can be seen that the dichlorvos + chlorpyrifos combination led to deleterious effects on the reproductive parameters of the detached and pre-selected female ticks (egg mass weight and hatching percentage) after the respective treatment, in comparison with $R$. (B.) microplus females detached from the control group.

The acaricidal efficacy of the dichlorvos + chlorpyrifos combination, grouped in intervals of three days, reached levels superior to 95\% (arithmetic means) starting right between the $1^{\text {st }}$ and $4^{\text {th }}$ DPT. The maximum efficacy of $99.31 \%$ was reached by this formulation between the $5^{\text {th }}$ and $7^{\text {th }}$ DPT. Efficacy values

\footnotetext{
${ }^{1}$ Constant corresponding to an estimate of the number of larvae contained in $1 \mathrm{~g}$ of eggs.
} 
Table 1. Results of multiple comparisons of the reproductive parameters of engorged Rhipicephalus (Boophilus) microplus females naturally detached and pre-selected from control and treated cattle, CPPAR, Jaboticabal, São Paulo State, Brazil.

\begin{tabular}{|c|c|c|c|c|c|}
\hline \multirow{2}{*}{$\begin{array}{c}\text { Experimental } \\
\text { Period }\end{array}$} & \multirow{2}{*}{$\begin{array}{c}\text { Reproductive } \\
\text { Parameter }\end{array}$} & \multicolumn{2}{|c|}{$\begin{array}{c}\text { Experimental Groups/Means and Standard } \\
\text { Deviation }{ }^{1}\end{array}$} & \multicolumn{2}{|c|}{ Variance Analysis } \\
\hline & & Control & $\begin{array}{l}\text { Dichlorvos } 60 \%+ \\
\text { Chlorpyrifos } 20 \% *\end{array}$ & Value of $F$ & $\operatorname{Pr}<F$ \\
\hline 1 to 4 & \multirow{10}{*}{ 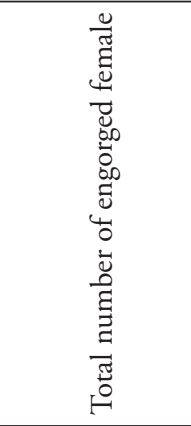 } & $20.0 \mathrm{~A}$ & $20.0 \mathrm{~A}$ & 1.74 & 0.2201 \\
\hline 5 to 7 & & $20.0 \mathrm{~A}$ & $5.0 \mathrm{~B}$ & 7.54 & 0.0226 \\
\hline 8 to 10 & & $20.0 \mathrm{~A}$ & $20.0 \mathrm{~A}$ & 0.05 & 0.8310 \\
\hline 11 to 13 & & $20.0 \mathrm{~A}$ & $20.0 \mathrm{~A}$ & 0.00 & 1,0000 \\
\hline 14 to 16 & & $20.0 \mathrm{~A}$ & $20.0 \mathrm{~A}$ & 0.43 & 0.5264 \\
\hline 17 to 19 & & $20.0 \mathrm{~A}$ & $10.0 \mathrm{~B}$ & 4.35 & 0.0465 \\
\hline 20 to 22 & & $20.0 \mathrm{~A}$ & $18.0 \mathrm{~A}$ & 2.04 & 0.1871 \\
\hline 23 to 25 & & $20.0 \mathrm{~A}$ & $20.0 \mathrm{~A}$ & 0.00 & 1.0000 \\
\hline 26 to 28 & & $20.0 \mathrm{~A}$ & $20.0 \mathrm{~A}$ & 0.00 & 1.0000 \\
\hline 29 to 30 & & $20.0 \mathrm{~A}$ & $20.0 \mathrm{~A}$ & 0.00 & 1.0000 \\
\hline \multicolumn{2}{|c|}{ Value of $F$} & 0.00 & 2.00 & & \\
\hline \multicolumn{2}{|c|}{$\operatorname{Pr}<\mathrm{F}$} & 1.0000 & 0.1582 & & \\
\hline 1 to 4 & & $4.3 \pm 0.2 \mathrm{~A}$ & $2.2 \pm 0.2 \mathrm{~B}$ & 3.2 & 0.0410 \\
\hline 5 to 7 & क्रि & $5.2 \pm 0.1 \mathrm{~A}$ & $1.3 \pm 0.0 \mathrm{~B}$ & 8.53 & 0.0170 \\
\hline 8 to 10 & $\frac{\vec{E}}{000}$ & $4.1 \pm 0.4 \mathrm{~A}$ & $4.3 \pm 0.2 \mathrm{~A}$ & 0.02 & 0.8907 \\
\hline 11 to 13 & $\overrightarrow{\bar{s}}$ & $4.6 \pm 0.7 \mathrm{~A}$ & $4.5 \pm 0.9 \mathrm{~A}$ & 0.00 & 0.9635 \\
\hline 14 to 16 & $\frac{\varkappa}{\pi}$ & $4.8 \pm 0.5 \mathrm{~A}$ & $4.1 \pm 0.7 \mathrm{~A}$ & 0.37 & 0.5555 \\
\hline 17 to 19 & ह్ّㄹ & $4.5 \pm 0.2 \mathrm{~A}$ & $3.1 \pm 1.2 \mathrm{~A}$ & 1.07 & 0.3271 \\
\hline 20 to 22 & $\vec{B}_{\infty}$ & $4.8 \pm 0.1 \mathrm{~A}$ & $3.3 \pm 0.8 \mathrm{~A}$ & 2.27 & 0.1660 \\
\hline 23 to 25 & 峁 & $4.6 \pm 0.2 \mathrm{~A}$ & $4.8 \pm 0.2 \mathrm{~A}$ & 0.02 & 0.8907 \\
\hline 26 to 28 & 도 & $4.7 \pm 0.3 \mathrm{~A}$ & $5.2 \pm 0.1 \mathrm{~A}$ & 0.00 & 0.9635 \\
\hline 29 to 30 & & $5.0 \pm 0.3 \mathrm{~A}$ & $5.1 \pm 0.3 \mathrm{~A}$ & 0.37 & 0.5555 \\
\hline \multicolumn{2}{|c|}{ Value of F } & 0.24 & 2.22 & & \\
\hline \multicolumn{2}{|c|}{$\operatorname{Pr}<\mathrm{F}$} & 0.9779 & 0.1248 & & \\
\hline 1 to 4 & \multirow{10}{*}{ 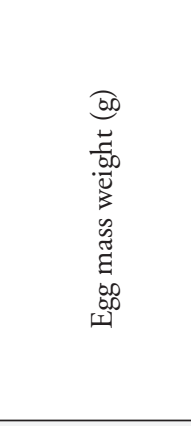 } & $0.7 \pm 0.2 \mathrm{~A}$ & $0.7 \pm 0.1 \mathrm{~A}$ & 0.00 & 1.0000 \\
\hline 5 to 7 & & $1.4 \pm 0.2 \mathrm{~A}$ & $0.2 \pm 0.1 \mathrm{~B}$ & 4.16 & 0.0317 \\
\hline 8 to 10 & & $1.9 \pm 0.2 \mathrm{~A}$ & $1.0 \pm 0.0 \mathrm{~B}$ & 1.4 & 0.0377 \\
\hline 11 to 13 & & $1.8 \pm 0.2 \mathrm{~A}$ & $0.6 \pm 0.2 \mathrm{~A}$ & 1.95 & 0.1961 \\
\hline 14 to 16 & & $1.5 \pm 0.3 \mathrm{~A}$ & $0.6 \pm 0.2 \mathrm{~A}$ & 2.6 & 0.1416 \\
\hline 17 to 19 & & $1.9 \pm 0.2 \mathrm{~A}$ & $0.6 \pm 0.1 \mathrm{~A}$ & 3.74 & 0.0852 \\
\hline 20 to 22 & & $1.4 \pm 0.4 \mathrm{~A}$ & $0.7 \pm 0.2 \mathrm{~A}$ & 1.4 & 0.2677 \\
\hline 23 to 25 & & $1.3 \pm 0.4 \mathrm{~A}$ & $1.7 \pm 0.5 \mathrm{~A}$ & 0.42 & 0.5354 \\
\hline 26 to 28 & & $2.1 \pm 0.1 \mathrm{~A}$ & $2.2 \pm 0.1 \mathrm{~A}$ & 0.18 & 0.6776 \\
\hline 29 to 30 & & $1.9 \pm 0.0 \mathrm{~A}$ & $2.0 \pm 0.3 \mathrm{~A}$ & 0.00 & 1.0000 \\
\hline \multicolumn{2}{|c|}{ Value of $F$} & 1.10 & 3.05 & & \\
\hline \multicolumn{2}{|c|}{$\operatorname{Pr}<\mathbf{F}$} & 0.4460 & 0.0560 & & \\
\hline 1 to 4 & \multirow{10}{*}{ 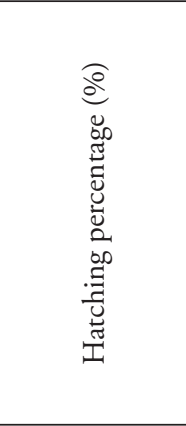 } & $85.7 \pm 4.2 \mathrm{~A}$ & $66.7 \pm 8.9 \mathrm{~A}$ & 0.48 & 0.5076 \\
\hline 5 to 7 & & $97.3 \pm 1.2 \mathrm{~A}$ & $22.5 \pm 2.1 \mathrm{~B}$ & 7.39 & 0.0237 \\
\hline 8 to 10 & & $98.0 \pm 2.0 \mathrm{~A}$ & $42.0 \pm 5.6 \mathrm{~B}$ & 4.14 & 0.0425 \\
\hline 11 to 13 & & $93.7 \pm 4.2 \mathrm{~A}$ & $41.7 \pm 2.8 \mathrm{~B}$ & 1.35 & 0.0451 \\
\hline 14 to 16 & & $94.7 \pm 4.0 \mathrm{~A}$ & $32.0 \pm 1.4 \mathrm{~B}$ & 5.18 & 0.0489 \\
\hline 17 to 19 & & $92.0 \pm 8.2 \mathrm{~A}$ & $36.0 \pm 5.6 \mathrm{~B}$ & 4.14 & 0.0425 \\
\hline 20 to 22 & & $81.7 \pm 1.8 \mathrm{~A}$ & $60.3 \pm 9.8 \mathrm{~A}$ & 0.6 & 0.4584 \\
\hline 23 to 25 & & $84.0 \pm 3.4 \mathrm{~A}$ & $73.3 \pm 5.7 \mathrm{~A}$ & 0.15 & 0.7075 \\
\hline 26 to 28 & & $94.3 \pm 1.5 \mathrm{~A}$ & $96.7 \pm 3.2 \mathrm{~A}$ & 0.01 & 0.9343 \\
\hline 29 to 30 & & $93.5 \pm 2.5 \mathrm{~A}$ & $93.0 \pm 3.0 \mathrm{~A}$ & 0.00 & 0.9859 \\
\hline \multicolumn{2}{|c|}{ Value of $F$} & 0.09 & 1.68 & & \\
\hline \multicolumn{2}{|c|}{$\operatorname{Pr}<\mathrm{F}$} & 0.9994 & 0.2264 & & \\
\hline
\end{tabular}

1: Means followed by the same letter in the line do not differ $(\mathrm{P}>0.05) ;{ }^{*}$ Commercial formulation purchased in the local market. 
superior to $95 \%$ lasted until the $22^{\text {nd }}$ DPT. Between days 23 and 25 post-treatment, the efficacy decreased to $93.53 \%$. These values continued to decrease between the $26^{\text {th }}$ and $28^{\text {th }}$ DPT $(11.97 \%)$ and the $29^{\text {th }}$ and $31^{\text {st }}$ DPT $(0.00 \%)$, when the trial was concluded (Table 3).

The formulation containing 60\% dichlorvos $+20 \%$ chlorpyrifos, administered as a whole-body spray, demonstrated elevated acaricidal efficacy and also presented deleterious effects on the reproductive parameters of $R$. (B.) microplus females, significantly diminishing $(\mathrm{P} \leq 0.05)$ the number of fully engorged female ticks collected (between the $5^{\text {th }}$ and $7^{\text {th }}$ and the $17^{\text {th }}$ and $19^{\text {th }}$ DPT), the weight of these females (between the $1^{\text {st }}$ and $7^{\text {th }}$ DPT), the weight of egg masses obtained (from day 5 until day 10 post-treatment) and the larval hatchability (from the $5^{\text {th }}$ to the $19^{\text {th }}$ DPT). The absence of studies conducted with the same active agents used on the present study, regarding the effects of these agents on the reproductive parameters of fully engorged $R$. (B.) microplus females, makes it impossible to make comparisons with the results obtained. The majority of the studies that have been conducted using spray formulations aimed to detect the resistance of $R$. (B.) microplus towards these compounds using in vitro methodologies, such as the Adult Immersion Test (AIT), Larval Packet Test (LPT) or Larval Immersion Test (LIT). Of these, the second test is recognized by the Food and Agriculture Organization (FAO) as a standard for evaluating the efficacy or resistance (CASTRO et al., 1997; FAO, 2003; ALONSODIÁZ et al., 2006; LOVIS et al., 2013; LOPES et al., 2014).

The first studies evaluating the reproductive parameters of female fully engorged ticks, detached from experimentally infested animals that had been treated with macrocyclic lactones, were conducted by Gonzales et al. (1993) and George \& Davey (2004), using doramectin administered as a pour-on $(500 \mathrm{mcg} / \mathrm{kg})$ and subcutaneously $(200 \mathrm{mcg} / \mathrm{kg})$. Pereira (2009) evaluated the effects of ivermectin, abamectin and doramectin, all administered subcutaneously at a dosage of $200 \mathrm{mcg} / \mathrm{kg}$, on the average and the reduction in oviposition among engorged females collected from experimentally infested animals that were kept in fields. More recently, Lopes et al. (2013) evaluated the effect of ivermectin,

Table 2. Results of multiple comparisons of the reproductive parameters of engorged Rhipicephalus (Boophilus) microplus females naturally detached and pre-selected from control and treated cattle during the 30-day post-treatment period, CPPAR, Jaboticabal, São Paulo State, Brazil.

\begin{tabular}{|c|c|c|c|c|}
\hline \multirow[b]{2}{*}{ Parameter } & \multicolumn{2}{|c|}{ Mean value*/Experimental groups } & \multicolumn{2}{|c|}{ Test F } \\
\hline & Control & $\begin{array}{c}\text { Dichlorvos } 60 \%+ \\
\text { Chlorpyrifos 20\%** }\end{array}$ & Value & $\begin{array}{c}\text { Significance prob- } \\
\text { ability }\end{array}$ \\
\hline No. of engorged female & $20.00 \mathrm{~A}^{*}$ & $17.30 \mathrm{~A}$ & 6.78 & 0.5662 \\
\hline Engorged female weigth (g) & $5.2 \mathrm{~A}$ & $4.0 \mathrm{~A}$ & 3.12 & 0.0532 \\
\hline Egg mass weight (g) & $1.6 \mathrm{~A}$ & $1.1 \mathrm{~B}$ & 0.69 & 0.0304 \\
\hline Hatchability (\%) & $91.5 \mathrm{~A}$ & $58.4 \mathrm{~B}$ & 4.33 & 0.0311 \\
\hline Reduction in oviposition (\%) & - & 31.3 & \multicolumn{2}{|c|}{ Not applicable } \\
\hline Reduction in hatchability (\%) & - & 36.2 & \multicolumn{2}{|c|}{ Not applicable } \\
\hline Reproductive efficiency & 632115.00 & 318572.00 & \multicolumn{2}{|c|}{ Not applicable } \\
\hline Efficacy $(\%)$ & - & 49.6 & \multicolumn{2}{|c|}{ Not applicable } \\
\hline
\end{tabular}

* Means followed by the same letter in the line do not differ $(\mathrm{P}>0.05)$; ${ }^{* *}$ Commercial formulation purchased in the local market.

Table 3. Average number of engorged Rhipicephalus (Boophilus) microplus females naturally detached from control and treated cattle and percent efficacy (arithmetic means), CPPAR, Jaboticabal, São Paulo State, Brazil.

\begin{tabular}{|c|c|c|c|c|c|}
\hline \multirow{2}{*}{ Experimental Period } & \multicolumn{2}{|c|}{$\begin{array}{c}\text { Experimental Groups/Means and } \\
\text { Standard Deviation }^{1} \\
\end{array}$} & \multirow{2}{*}{$\begin{array}{c}\text { Efficacy (\%) } \\
\text { T02 }\end{array}$} & \multicolumn{2}{|c|}{ Variance Analysis } \\
\hline & T01: control & $\begin{array}{c}\text { T02: } 60 \% \text { DDVP + } \\
\text { 20\% Clorpirifós }\end{array}$ & & Value of $F$ & $\operatorname{Pr}<F$ \\
\hline 0 & $40.17 \mathrm{~A}$ & $40.67 \mathrm{~A}$ & - & 0.00 & 0.9878 \\
\hline 1 to 4 & $39.61 \mathrm{~A}$ & $1.94 \mathrm{~B}$ & 95.15 & 104.03 & $<0.0001$ \\
\hline 5 to 7 & $39.56 \mathrm{~A}$ & $0.28 \mathrm{~B}$ & 99.31 & 150.27 & $<0.0001$ \\
\hline 8 to 10 & $39.44 \mathrm{~A}$ & $1.27 \mathrm{~B}$ & 95.83 & 95.39 & $<0.0001$ \\
\hline 11 to 13 & $39.61 \mathrm{~A}$ & $2.44 \mathrm{~B}$ & 93.90 & 72.23 & $<0.0001$ \\
\hline 14 to 16 & $40.89 \mathrm{~A}$ & $1.33 \mathrm{~B}$ & 96.78 & 98.41 & $<0.0001$ \\
\hline 17 to 19 & $43.17 \mathrm{~A}$ & $0.61 \mathrm{~B}$ & 98.60 & 135.19 & $<0.0001$ \\
\hline 20 to 22 & $45.28 \mathrm{~A}$ & $1.00 \mathrm{~B}$ & 97.82 & 134.60 & $<0.0001$ \\
\hline 23 to 25 & $47.39 \mathrm{~A}$ & $3.11 \mathrm{~B}$ & 93.52 & 80.80 & $<0.0001$ \\
\hline 26 to 28 & $61.83 \mathrm{~A}$ & $55.11 \mathrm{~A}$ & 11.97 & 0.860 & 0.3562 \\
\hline 29 to 30 & $39.42 \mathrm{~A}$ & $39.42 \mathrm{~A}$ & 0.00 & 0.010 & 0.9274 \\
\hline Value de F & 0.28 & 48.71 & & & \\
\hline $\operatorname{Pr}<\mathrm{F}$ & 0.9848 & $<0.0001$ & & & \\
\hline
\end{tabular}

1: Means followed by the same letter in the line do not differ $(\mathrm{P}>0.05) ;{ }^{*}$ Commercial formulation purchased in the local market. 
abamectin, doramectin and moxidectin on the reproductive parameters of fully engorged females of $R$. (B.) microplus.

For doramectin $(700 \mathrm{mcg} / \mathrm{kg})$, the results found by Lopes et al. (2013), regarding the reduction in oviposition among female ticks exposed to this formulation (62.17\%), were slightly inferior to those obtained by Gonzales et al. (1993) (99.9\%), George \& Davey (2004) (91.43\%) and Pereira (2009) (83.51\%), all of whom used doramectin administered as a pour-on $(500 \mathrm{mcg} /$ $\mathrm{kg}$ ) or subcutaneously $(200 \mathrm{mcg} / \mathrm{kg})$, respectively. For abamectin administered subcutaneously $(200 \mathrm{mcg} / \mathrm{kg})$, Pereira (2009) found that this formulation provided a percentage reduction of $37.11 \%$ in the oviposition among engorged females exposed to this active agent. These results were similar to those obtained by Lopes et al. (2013), who used abamectin as a pour-on $(500 \mathrm{mcg} /$ $\mathrm{kg}$ ). Regarding ivermectin, Pereira (2009) observed a $63.92 \%$ reduction in oviposition among ticks exposed to $200 \mathrm{mcg} / \mathrm{kg}$ ivermectin, while Lopes et al. (2013), evaluating the same agent at a dosage of $630 \mathrm{mcg} / \mathrm{kg}$, attained a $46.31 \%$ reduction in oviposition among engorged $R$. (B.) microplus females exposed to ivermectin. These authors explained that this difference may be related to the degree of resistance of different tick strains against ivermectin. However, it is important to emphasize that the average acaricidal efficacy values obtained from ivermectin during the whole experimental period were similar to those in the studies conducted by Lopes et al. (2013), in which $630 \mathrm{mcg} /$ $\mathrm{kg}$ ivermectin reached $77.88 \%$ efficacy, and by Pereira (2009), in which $200 \mathrm{mcg} / \mathrm{kg}$ ivermectin reached an efficacy of $72.70 \%$.

Among all the macrocyclic lactones evaluated (abamectin, ivermectin, doramectin and moxidectin), Lopes et al. (2013) found that doramectin and moxidectin were the ones that presented superior acaricidal efficacy and deleterious effects over the reproductive parameters of fully engorged $R$. (B.) microplus females. These authors mentioned that the differences in effect can be explained by variations between the formulations, caused by absorption of the active agent, which is subject to interference from the quality of each molecule and/or components of the vehicles used (TOUTAIN et al., 1997; AGUILAR-TIPACAMÚ \& RODRÍGUEZ-VIVAS, 2002). Furthermore, few commercial products based on doramectin and moxidectin are yet available on the Brazilian veterinary market (SINDAN, 2008: Compendium of Veterinary Products).

Martins et al. (1995) studied the effect of fluazuron on the reproductive performance of $R$. (B.) microplus. Using different fluazuron concentrations $(1 \mathrm{mg} / \mathrm{kg}$ and $2 \mathrm{mg} / \mathrm{kg}$ ), these authors found that there was either no oviposition among the engorged females on days 7-11 or it occurred at very low percentages $(<15 \%)$. In another study, Mendonça (2010) evaluated a formulation of $3.0 \mathrm{mg} / \mathrm{kg}$ of fluazuron $+0.5 \mathrm{mg} / \mathrm{kg}$ of abamectin on a different strain of $R$. (B.) microplus. They observed that this compound had deleterious effects on the reproductive parameters of fully engorged $R$. (B.) microplus females, showing $100 \%$ efficacy on several post-treatment days. Despite the results obtained, Mendonça (2010) emphasized that because of the high sensitivity of the $R$. (B.) microplus strain that was evaluated, it was not possible to collect a minimum of 10 fully engorged females detached from treated animals $(3.0 \mathrm{mg} / \mathrm{kg}$ of fluazuron $+0.5 \mathrm{mg} /$ $\mathrm{kg}$ of abamectin) on some post-treatment days. This interfered directly with the total number of preselected females, the weights of these females and the weights of the egg masses during this period. Similar results were obtained with different compound containing fluazuron by Cruz et al. (2014). According to these authors, a formulation can lead to deleterious effects on $R$. (B.) microplus females if this compound reaches elevated percentages (above 95-99\%). In other words, this can occur when the $R$. (B.) microplus strain analyzed presents elevated sensitivity. The results from the $60 \%$ dichlorvos $+20 \%$ chlorpyrifos combination in this study can possibly be correlated with these authors' assertion. However, further studies need to be conducted with the objective of verifying this hypothesis.

\section{Conclusions}

Based on the data and results from the present study, it is possible to conclude that this association of organophosphates (60\% dichlorvos $+20 \%$ chlorpyrifos), administered to animals as a whole-body spray, demonstrated elevated acaricidal efficacy, as well as deleterious effects on the reproductive parameters of $R$. (B.) microplus females, thereby significantly decreasing $(\mathrm{P} \leq 0.05)$ the number of ticks collected (from the $5^{\text {th }}$ to the $7^{\text {th }}$ and from the $17^{\text {th }}$ to the $19^{\text {th }} \mathrm{DPT}$ ), the weight of egg masses (between days 5 and 10 post-treatment) and the larval hatching percentage (between the $5^{\text {th }}$ and the $19^{\text {th }}$ DPT). The results from this combination of $60 \%$ dichlorvos $+20 \%$ chlorpyrifos can possibly be correlated with the high sensitivity of the strain used. However, further studies need to be conducted with the objective of verifying this hypothesis.

\section{References}

Aguilar-Tipacamú G, Rodríguez-Vivas RI. Uso de la moxidectina para el tratamiento de los parásitos internos y externos de los animales. Rev Biomed 2002; 13(1): 43-51.

Alonso-Díaz MA, Rodríguez-Vivas R, Fragoso-Sánchez H, RosarioCruz R. Resistencia de la garrapata Boophilus microplus a los ixodicidas. Arch Med Vet 2006; 38(2): 105-114. http://dx.doi.org/10.4067/S0301732X2006000200003.

Brasil. Ministério da Agricultura e Abastecimento. Secretaria de Defesa Agropecuária. Portaria no 48, de 12 maio de 1997. Diário Oficial da Uniāo. 1997. Available from: http://www.adivaldofonseca.vet.br/

Calligaris IB, Oliveira PR, Roma GC, Bechara GH, Camargo-Mathias MI. Action of the insect growth regulator fluazuron, the active ingredient of the acaricide Acatak ${ }^{\oplus}$, in Rhipicephalus sanguineus nymphs (Latreille, 1806) (Acari: Ixodidae). Microsc Res Tech 2013; 76(11): 1177-1185. http://dx.doi.org/10.1002/jemt.22282. PMid:24000046

Cruz BC, Teixeira WF, Maciel WG, Felippelli G, Fávero FC, Cruz AC, et al. Effects of fluazuron $(2.5 \mathrm{mg} / \mathrm{kg})$ and a combination of fluazuron $(3.0 \mathrm{mg} / \mathrm{kg})+$ abamectin $(0.5 \mathrm{mg} / \mathrm{kg})$ on the reproductive parameters of a field population of Rhipicephalus (Boophilus) microplus on experimentally infested cattle. Res Vet Sci 2014; 97(1): 80-84. http:// dx.doi.org/10.1016/j.rvsc.2014.04.012. PMid:24837997

Castro JJ. Sustainable tick and tickborne disease control in livestock improvement in developing countries. Vet Parasitol 1997; 71(2-3): 77-97. http://dx.doi.org/10.1016/S0304-4017(97)00033-2. PMid:9261972 
Drummond RO, Ernst SE, Trevino JL, Gladney WJ, Graham OH. Boophilus annulatus and B. microplus: laboratory tests of insecticides. $J$ Econ Entomol 1973; 66(1): 130-133. PMid:4690254.

Faza AP, Pinto ISB, Fonseca I, Antunes GR, Monteiro CMO, Daemon E, et al. A new approach to characterization of the resistance of populations of Rhipicephalus microplus (Acari: Ixodidae) to organophosphate and pyrethroid in the state of Minas Gerais, Brazil. Exp Parasitol 2013; 134(4): 519-523. http://dx.doi.org/10.1016/j.exppara.2013.04.006. PMid:23639866

Food and Agriculture Organization of the United Nations - FAO. Resistencia a los antiparasitarios: estado actual com énfasis em América Latina. Roma; 2003.

Furlong J. Carrapatos: problemas e soluçôes. Juiz de Fora: Embrapa Gado de Leite; 2005. 65 p.

George JE, Davey RB. Therapeutic and persistent efficacy of a single application of doramectin applied either as a pour-on or injection to cattle infested with Boophilus microplus (Acari: Ixodidae). J Med Entomol 2004; 41(3): 402-407. http://dx.doi.org/10.1603/0022-2585-41.3.402. PMid:15185941

Gonzales JC, Muniz RA, Farias A, Gonçalves LCB, Rew RS. Therapeutic and persistent efficacy of doramectin against Boophilus microplus in cattle. Vet Parasitol 1993; 49(1): 107-119. http://dx.doi.org/10.1016/03044017(93)90229-G. PMid:8236733

Holdsworth PA, Kemp D, Green P, Peter RJ, De Bruin C, Jonsson NN, et al, and the World Association for the Advancement of Veterinary Parasitology. World Association for the Advancement of Veterinary Parasitology (W.A.A.V.P.) guidelines for evaluating the efficacy of acaricides against ticks (Ixodidae) on ruminants. Vet Parasitol 2006; 136(1): 29-43. http://dx.doi.org/10.1016/j.vetpar.2005.11.011. PMid: 16377090

Klafke GM, Sabatini GA, Albuquerque TA, Martins JR, Kemp DH, Miller RJ, et al. Larval immersion tests with ivermectin in populations of the cattle tick Rhipicephalus (Boophilus) microplus (Acari: Ixodidae) from State of Sao Paulo, Brazil. Vet Parasitol 2006; 142(3-4): 386-390. http:// dx.doi.org/10.1016/j.vetpar.2006.07.001. PMid:16904265

Lopes WDZ, Teixeira WFP, Matos LV, Felippelli G, Cruz BC, Maciel WG, et al. Effects of macrocyclic lactones on the reproductive parameters of engorged Rhipicephalus (Boophilus) microplus females detached from experimentally infested cattle. Exp Parasitol 2013; 135(1): 72-78. http:// dx.doi.org/10.1016/j.exppara.2013.06.003. PMid:23792004
Lopes WDZ, Cruz BC, Teixeira WF, Felippelli G, Maciel WG, Buzzulini C, et al. Efficacy of fipronil (1.0 mg/kg) against Rhipicephalus (Boophilus) microplus strains resistant to ivermectin $(0.63 \mathrm{mg} / \mathrm{kg})$. Prev Vet Med 2014; 115(3-4): 88-93. http://dx.doi.org/10.1016/j.prevetmed.2014.04.009. PMid:24853051

Lovis L, Mendes MC, Perret JL, Martins JR, Bouvier J, Betschart B, et al. Use of the Larval Tarsal Test to determine acaricide resistance in Rhipicephalus (Boophilus) microplus Brazilian field populations. Vet Parasitol 2013; 191(3-4): 323-331. http://dx.doi.org/10.1016/j. vetpar.2012.09.011. PMid:23059136

Martins JR, Correa BL, Ceresér VH. Ação carrapaticida do Fluazuron, formulação "pour-on", sobre o carrapato bovino Boophilus microplus. Pesq Agrop Gaúcha 1995; 1(2): 257-261.

Mendonça RP. Atividade endectocida, segurança clinica, e farmacocinética de residuos de uma nova alternativa terapêutica (Fluazuron + Abamectina) em bovinos [Tese]. Jaboticabal: Universidade Estadual Paulista; 2010.

Pereira MC, Labruna MB, Szabó MPJ, Klafke GM. Rhipicephalus (Boophilus) microplus: biologia, controle e resistência. São Paulo: MedVet; 2008.

Pereira JR. The efficiency of avermectins (abamectin, doramectin and ivermectin) in the control of Boophilus microplus, in artificially infested bovines kept in field conditions. Vet Parasitol 2009; 162(1-2): 116-119. http://dx.doi.org/10.1016/j.vetpar.2009.02.014. PMid:19286322

Santana BB, Ramos RAN, Santana MA, Alves LC, Carvalho GA. Susceptibility of Rhipicephalus (Boophilus) microplus (Acari: Ixodidae) to pyrethroids and their associations in Pernambuco, Brazil. Rev Bras Parasitol Vet 2013; 22(2): 276-280. http://dx.doi.org/10.1590/S198429612013000200047. PMid:23856731

SAS Institute. SAS ${ }^{\circledast}$ User's guide: Estatistics. Cary; 1996.

Sindicato Nacional da Indústria de Produtos para Saúde Animal SINDAN. Mercado veterinário. São Paulo; 2008. Available from: http:// www.sindan.org.br/sd/

Toutain PL, Upson DW, Terhune TN, McKenzie ME. Comparative pharmacokinetics of doramectin and ivermectin in cattle. Vet Parasitol 1997; 72(1): 3-8. http://dx.doi.org/10.1016/S0304-4017(97)00070-8. PMid:9403971

Wharton RH. The current status and prospects for control of ixodid ticks with special emphasis on Boophilus microplus. Bull Off in Epizoot 1974; 81(2): 65-85. 